\title{
Ultrasonic pulse technique for evaluation of mechanical damage in processed coffee beans
}

\section{Técnica de pulso ultrassônico para avaliação de danos mecânicos em grãos de café beneficiados}

\author{
Mariana de Oliveira e Silva ${ }^{1 *}$; Francisco Carlos Gomes ${ }^{2}$; \\ Stella Dellyzete Veiga Franco da Rosa ${ }^{3}$
}

\begin{abstract}
The knowledge of the physical characteristics of the coffee bean allows the transition from the conventional storage model in bags to the silo storage, and as an indirect measure of the improvement and conservation of the quality of the stored grain. The elastic modulus allows comparisons on the strength of material. The variations of this occur due to its chemical composition, microstructures and material defects, being able to be used as indicator of the physical integrity of the grain. The ultrasonic pulse technique is an alternative to obtain the elastic modulus in a simple and non-destructive way. In this context, it was proposed the development of a non-destructive methodology that will perform the quality evaluation by determining the elastic modulus of the coffee beans. For this purpose, a reference silo was constructed, reproducing the storage conditions, and the elastic modulus values were determined. The values obtained by the Stress Wave Timer apparatus are between 2.54 and $4.23 \mathrm{MPa}$, with a maximum load of $8.32 \mathrm{kN}$, and a calculated vertical pressure of $1,526 \mathrm{kPa}$. To evaluate the impact of the storage conditions and the loads applied during the non-destructive test, laboratory tests applied in seeds were performed, and the tetrazolium test was the only one able to differentiate the samples. It was concluded that Stress Wave Timer was able to determine the elastic modulus values for the coffee bean mass and could be used as an indicative of the quality.
\end{abstract}

Key words: Elastic modulus. Stress Wave Timer. Compression test.

\section{Resumo}

O conhecimento das características físicas do grão de café permite a transição do modelo de armazenamento convencional em sacarias para o armazenamento em silos e como medida indireta da melhoria e conservação da qualidade do grão armazenado. O módulo de elasticidade permite comparações de resistência do material. As variações deste ocorrem devido à sua composição química, microestruturas e defeitos do material, podendo ser utilizado como indicador da integridade física do grão. A técnica de pulso ultrassônico é uma alternativa para obtenção do módulo de elasticidade de forma simples e não destrutiva. Nesse contexto, foi proposto o desenvolvimento de uma metodologia não destrutiva que realize a avaliação da qualidade por meio da determinação do módulo de elasticidade dos grãos de café. Para tanto um silo modelo foi construído, reproduzindo as condições de armazenamento, e os valores do módulo de elasticidade foram determinados. Os valores obtidos pelo aparelho Stress Wave Timer se encontram entre 2,54 a 4,23 MPa, com carga máxima exercida de 8,32 kN e pressão vertical calculada $1,526 \mathrm{kPa}$. Para avaliar o impacto das condições de armazenamento e das cargas

\footnotetext{
${ }^{1}$ Discente de Doutorado, Universidade Federal de Lavras, UFLA, Lavras, MG, Brasil. E-mail: marianaoesilva@gmail.com

2 Prof. Titular, UFLA, Lavras, MG, Brasil. E-mail: fcgomes@ufla.br

${ }^{3}$ Pesquisadora, Empresa Brasileira de Pesquisa Agropecuária, Embrapa Café, Brasília, DF, Brasil. E-mail: sttela.rosa@embrapa.br

* Author for correspondence
} 
aplicadas durante o ensaio não-destrutivo, testes laboratoriais, aplicados em sementes, foram realizados, sendo que o teste de tetrazólio foi o único capaz de diferenciar as amostras. Conclui-se que o Stress Wave Timer foi capaz de determinar os valores do módulo de elasticidade da massa de grãos de café, podendo ser utilizado como indicativo da qualidade.

Palavras-chave: Módulo de elasticidade. Stress Wave Timer. Teste de compressão.

\section{Introduction}

In the commercialization of agricultural products, there are regulatory laws that aim to measure the grain quality, using destructive tests. However, these tests are not representative of the whole lot and either require a lot of time and high costs to be executed. Although they are the standard for commercialization, the agribusiness requires that answers on the quality of the grains be obtained in a broader, faster and at a reduced cost.

Grain quality is affected during handling of the product, which can cause mechanical damage. Mechanical damage is a failure, a collapse in the structure that occurs in any material due to the action of forces. In coffee beans, the external mechanical damage results in financial loss, due to the loss of weight, and for seeds, the internal damage can preclude the germination. Grain quality testing can be performed according to the prediction of the behavior of a material when subjected to different types of loading. To this end, it is necessary to determine the mechanical properties with the elastic modulus as the highlight.

A thorough evaluation of mechanical damage requires special techniques and instrumentation. Some researches using optical techniques have been reported, such as Santos (2009), who applied the X-ray technique in the evaluation of the quality of papaya seeds, and Saath (2010), who used the scanning electron microscopy to evaluate the changes in the plasma membrane of the endosperm cell of the coffee beans as a function of the water content and drying time.

Theideal in determining themechanicalproperties is that they be obtained with tests that fit the nondestructive type based on physical phenomena. For the development of a non-destructive methodology that evaluates the quality of stored coffee beans, applied in large volumes, the knowledge of the elastic modulus appears as an economically viable choice because it is an indicative of indirect quality measurement. By means of mechanical vibration or application of electromagnetic energy, it is possible to determine properties of materials, such as its elastic modulus. Thereby, it is possible to detect the presence of discontinuities, such as failures and ruptures (SILVA JUNIOR; MARQUES, 2006).

An option to determine the elastic modulus is the ultrasonic pulse technique, which has a simple concept, easy to apply and has been widely used in determining the elastic modulus of solid materials. The technique consists in the generation of elastic waves through a solid and, the speed in which the wave propagates through the material is related to the elastic modulus and mass density. According to Mohsenin (1970), we can calculate the elastic modulus by means of Equation 1:

$$
E=\rho \times V^{2}
$$

where, $E$ is the elastic modulus, $\rho$ is the material density and $V$ is the velocity of the wave through the material.

Several authors have evaluated the presence of deterioration in biological or non-biological materials through this technique. Abreu (2013) used the technique to evaluate deterioration of structural elements of wood in historical constructions. Several tests have been developed in order to obtain the mechanical properties of soils and adapted for agricultural products, especially those stored in bulk. Wang et al. (2006) and Christ et al. (2009) used the ultrasound technique as a tool to determine the mechanical properties of frozen soils, proving 
that the technique is efficient in determining these parameters, including the elastic modulus.

It is also possible to determine the elastic modulus by means of the universal compression test. The test can be described as the application of a compression load, static or cyclic on test bodies. Zoerb (1960) used the uniaxial compression test between two rigid and parallel plates to evaluate the elastic modulus in meat, fruits and vegetables.

Laboratory tests provide results for the detection and evaluation of mechanical damage with the disadvantage of being destructive and using sampling plots. Silva Junior and Marques (2006) pointed out that these tests serve as calibration parameters for non-destructive tests. We can cite the tetrazolium test that is used to evaluate the vigor, viability of seeds, damages by drying, by insects and by humidity as well as mechanical damages of harvesting and/or processing. The electrical conductivity test is considered a good indicator of the integrity of the cell membrane system, being one of the fastest and most efficient for evaluating seed quality (ANDRADE et al, 1995). The X-ray test was standardized by the international seed testing association (ISTA, 1999) and, in Brazil, it is prescribed in the rules for seed analysis (BRASIL, 2009).

In this study, we propose to develop a nondestructive methodology that will evaluate the quality in large volumes of stored coffee beans. For this purpose, we analyzed the use of the ultrasonic pulse technique to determine the elastic modulus of coffee beans, considering it as an indirect measure of quality.

\section{Material and Methods}

For the experiment, commercial coffee samples were used. The grains were processed similarly to those used in agro-industry. Afterwards, the grain was separated according to its shape and size. The grains were manually selected, discarding the broken grains and shell type, with visible cracks, attacked by insects and barks. Grains of the mocha type, without visual damage, were also used. To perform the tests, as well as for the evaluations, the batch homogenization was carried out with the aid of the mechanical separator in order to obtain and divide in identical samples of $5 \mathrm{~kg}$, comprising 12 samples, or $60 \mathrm{~kg}$ in total.

The coffee beans were submitted to two types of mechanical tests and three laboratory tests. The mechanical uniaxial compression test and the ultrasonic pulse test occurred simultaneously. Laboratory tests to evaluate the effect and differentiation among treatments were composed of the tetrazolium test (endosperm only), electrical conductivity test and X-ray test. The tests followed the fully randomized design with three repetitions, and analyzes of variance were used the Scott-Knott test with 5\% significance.

The reference silo was loaded with the $5 \mathrm{~kg}$ samples for the mechanical tests. Before them, 0.1 $\mathrm{kg}$ were collected at the mean height of the reference silo to obtain the control, and after the tests, $0.1 \mathrm{~kg}$ were collected at the mean height of the reference silo for the accomplishment of the laboratory tests.

\section{Uniaxial compression test}

In order to perform the mechanical tests, a model similar to the test apparatus used by Chung (2006) and by Johnstone (2010) was constructed to perform confined compression experiments on glass beads and corn kernels. The model was constructed based on the European standards for measuring the lateral pressure ratio for silo projects (EN 1991-4, 2006). The experimental setup is shown in Figure 1.

The cylinder was fully loaded with the coffee beans and the compression test was started. In the test, the fixed load applied by the table was $30 \mathrm{kN}$ and the constant speed of table displacement of $2 \mathrm{~mm}$ $\min ^{-1}$. During this downward movement, the table was paused at predetermined heights to perform 
the reading by the ultrasonic pulse technique. The readings occurred in three measures of heights, called quotas. After the tests, samples of coffee beans were collected and submitted to laboratory tests to evaluate the effects of compression on the coffee beans.

Figure 1. Experimental setup for the compression test.

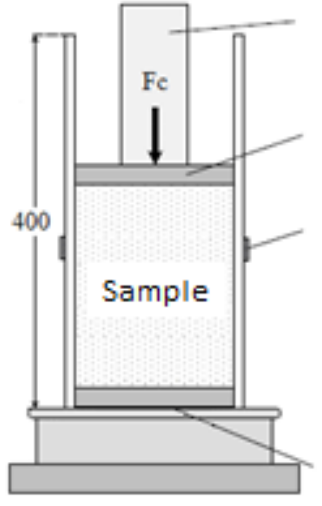

(a) Side view
Connection to the Universal Machine

Top platform

Reading point 2

Bottom platform

(fixture)

(All dimensions in $\mathrm{mm}$ )

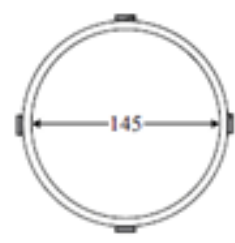

Acrylic cylinder

(b) Front view

\section{Ultrasonic pulse technique}

The ultrasonic pulse technique was performed using the Stress Wave Timer, model 239A, manufactured by Metriguard, with the hammershaped accessory. This equipment generates an elastic wave in a solid material and is able to measure the propagation time of this wave by a known distance, allowing the calculation of the velocity, as can be seen in Equation 2. Moreover, through the Equation 3, we can estimate the value of the elastic modulus.

$$
\begin{gathered}
v_{0}=\frac{\mathrm{L}}{\mathrm{t}} \\
E_{d}=\frac{v_{0}^{2} \times \mathrm{D}}{\mathrm{g}} \times 10^{-6}
\end{gathered}
$$

In Equation 2, we have that $v_{0}$ is the propagation velocity of the wave, $\mathrm{L}$ is the distance traveled by the wave in meters (m), and the transit time of the wave measured by the apparatus in milliseconds (ms). In Equation 3, we have $E_{d}$, which is the elastic modulus in $\mathrm{MPa}, \mathrm{g}$ is the gravitational acceleration and $\mathrm{D}$ is the mass density of grains in $\mathrm{kg} \mathrm{m}^{-3}$.

With the fully loaded prototype, measurements were made on the side of the silo at three different heights from three quotas of the reference silo, considering the lower part in the $100 \mathrm{~mm}$ quota, the central part $200 \mathrm{~mm}$ and the top $300 \mathrm{~mm}$, following a single direction. Data were obtained using two accelerometers: the first accelerometer, from which the strain wave is released, is hammer-shaped, and the second accelerometer, which receives the wave, has a cylindrical shape. There were markings indicating the heights and diameter of the prototype, allowing direct manual coupling on the curved surface in one side and the impact on the hammer in the other. Attention was need in order to ensure that the waveform impact occurred perpendicular to the reference silo and the second accelerometer was aligned with the impact point, following the diameter line of the reference silo, as seen in Figure 2. Thus, the time readings regarding the outward transit of the wave measured by the apparatus were performed in milliseconds (ms). 
Figure 2. Stress Wave Timer coupling position in the reference silo.

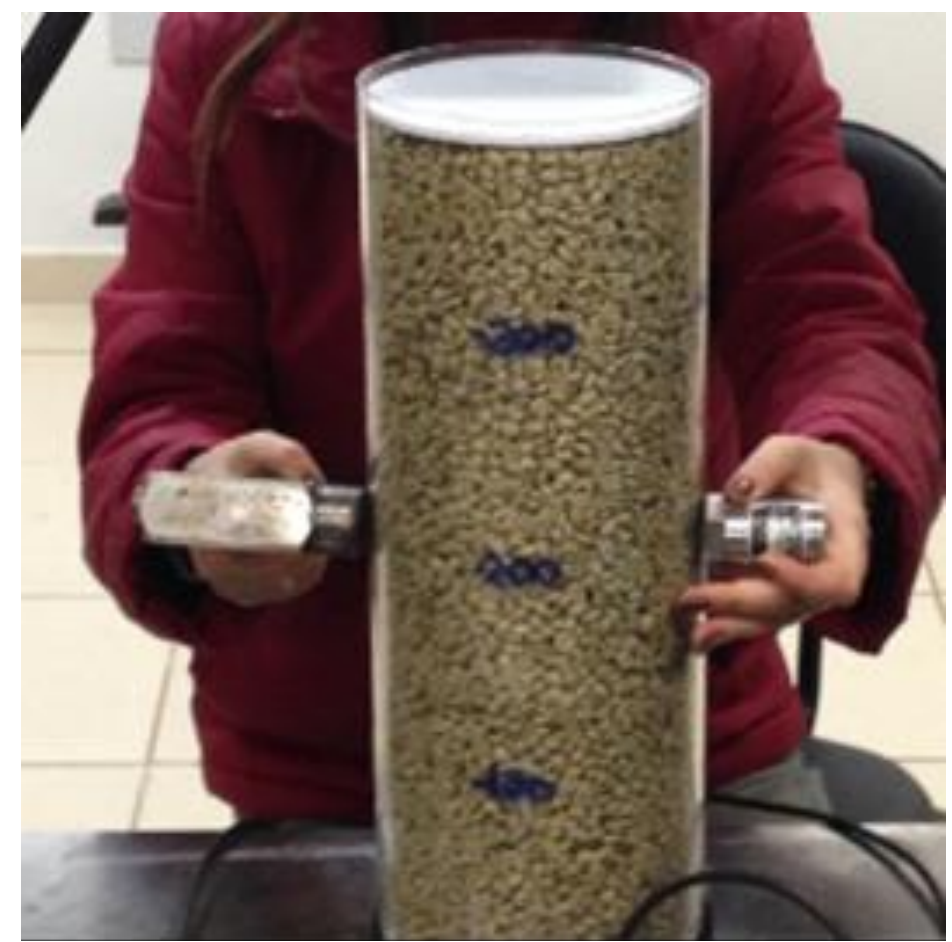

For each pre-determined pause, three readings were performed at three measurement heights. Three assays were performed, with three repetitions each. In the first assay, the predetermined descent heights of the test machine table were $5 \mathrm{~mm}$ and $10 \mathrm{~mm}$. In the second assay, the predetermined descent heights of the test machine table were $5 \mathrm{~mm}, 10 \mathrm{~mm}, 15 \mathrm{~mm}$, and $20 \mathrm{~mm}$. In the third assay, the predetermined descent heights of the test machine table were 5 $\mathrm{mm}, 10 \mathrm{~mm}, 15 \mathrm{~mm}, 20 \mathrm{~mm}, 25 \mathrm{~mm}$, and $30 \mathrm{~mm}$. In all assays, the readings were performed before the assay to disregard the compression effect at $0 \mathrm{~mm}$.

\section{Tetrazolium test}

The test was conducted with four replicates of 25 coffee beans from each assay that were randomly selected, discarding only the mocha type grains, so that there was a greater physical standardization in the reading of the results to perform the tetrazolium test. The test was performed only on the endosperm to verify external damages (VIEIRA, 1998). For the test, the beans were immersed for $48 \mathrm{~h}$ at $30^{\circ} \mathrm{C}$ in distilled water. Then, washing in distilled water and soaking in $1 \%$ tetrazolium solution were carried out in dark vials, kept at $30{ }^{\circ} \mathrm{C}$ for a period of $24 \mathrm{~h}$, during which time the staining occurred. After the staining, another washing was performed and the grains were placed for drying. The grains were then digitized by means of the Image Analysis System, an apparatus developed by the company Tbit, where there was an enlargement of the images for a better visualization of the defects that were stained by tetrazolium. Through visual evaluation, it was possible to classify the external damages of the grains according to the location and the extension.

Following a methodology similar to that applied by Freitas (2013) in order to evaluate coffee quality, a visual analysis of stained damages was performed, assigning grades from 1 to 3 . The analysis was performed by only one evaluator, aiming to standardize response and minimize possible errors. The classification of the damage staining was performed according to Figure 3: 
Using this scale of grades, the percentage of coffee beans corresponding to each grade in each repetition was counted. In order to obtain an integrated value for each repetition of the treatments, i.e., a value that has a variance from 0 (no damage) to $100 \%$ (maximum damage), the Equation 3 was used, which is an adaptation of the McKinney index(1923), one of the most used when you have complex data. With this equation and concept, the Severity of Damage Index (ISD) was determined with the ability to characterize the damage degree of the coffee beans.

Figure 3. Attribution of grades to the damages evidenced by the tetrazolium test. Note 1, grains with affected area less than 25\%; Note 2; Grains with affected area between 25 and 75\%; Note 3, grains with affected area greater than $75 \%$.

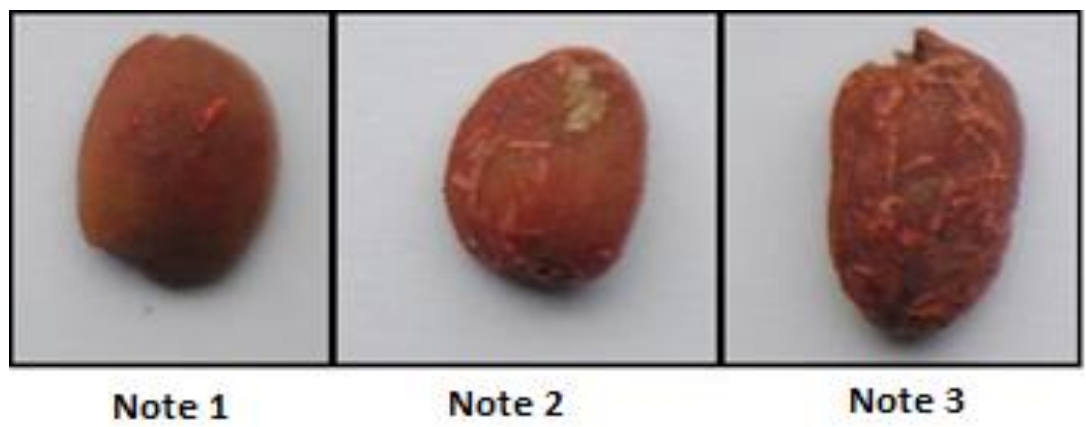

ISD $=\sum \frac{(\text { scale degree } \mathrm{x} \text { frequency })}{(\text { total numbers of unit } \mathrm{x} \text { maximum scale })} \times 100$

\section{Electrical conductivity test}

The test followed the one proposed by Malta et al. (2005) using two repetitions with 50 grains, taken at random, for each corresponding sample of the Uniaxial Compression Test and its respective control. Part of the methodology is an adaptation of the method proposed by Loeffler et al. (1988), where the grains were weighed to an accuracy of $0.001 \mathrm{~g}$ and then immersed in $75 \mathrm{~mL}$ of deionized water in $200 \mathrm{~mL}$ plastic cups. The vials were kept at $25{ }^{\circ} \mathrm{C}$ for $5 \mathrm{~h}$ in a vented oven. After this period, the electrical conductivity of the solution was read in the conductivity meter C-701. The electrical conductivity is obtained by reading the data, with the result being expressed in $\mathrm{mS} \mathrm{cm-1} \mathrm{g-1} \mathrm{of} \mathrm{sample.}$

\section{X-Ray test}

The test was conducted with four repetitions of 25 coffee beans from each treatment, which were randomly selected, removing only the mochatype grains, so that there was a standardization of the form for the X-ray test. The device used was the Faxitron X-ray, which performs automatic calibration of the intensity and exposure time of the beans, for each test.

The grains were glued onto a transparent slide, which was positioned at a height of $50 \mathrm{~cm}$ from the beam for image capture by the apparatus. In the software, it is possible to calibrate the shadow and the intensity of the obtained image and then save it in .jpeg. The automatic calibration of the device marked the exposure time of 1.3 secs and an intensity of $18 \mathrm{kV}$.

For evaluation, an adaptation of the method proposed by RAS (BRASIL, 2009) was used and this was due to the fact of the previous separation of the grains, so there were no empty seeds or insect damage. Therefore, the seed was classified as whole or with physical damages (cracks). Data were expressed as a percentage. 


\section{Results and Discussion}

Uniaxial compression test and ultrasonic pulse technique

The universal testing machine provided the stress-strain diagrams. Load values in $\mathrm{kN}$ were also given for each table movement. The Stress Wave
Timer provided the necessary data for the calculation of the elastic modulus by means of Equation 1. In Table 1, we can verify the mean values of the elastic modulus (Ed) obtained for each dimension in each type of test, being these values the means among the repetitions.

Table 1. Mean values of elastic modulus obtained with the compression test and the ultrasonic pulse technique.

\begin{tabular}{ccc}
\hline \multirow{2}{*}{ Assay } & \multicolumn{2}{c}{ Mean of elastic modulus (MPa) } \\
\cline { 2 - 3 } & Uniaxial Compression & Stress Wave Timer \\
\hline Quota 1 (0-100mm) & 5.27 & 2.54 \\
Quota 2 (0-200mm) & 6.09 & 2.83 \\
Quota 3 (0-250mm) & 6.18 & 4.23 \\
\hline
\end{tabular}

There is a gradual increase in the elastic modulus with increasing load. This is because the modulus value is dependent on the density of the sample, which increased in each treatment due to the greater compaction of the sample. Similarly, stress-strain curves, obtained by the Universal Testing Machine software for each repetition of each dimension, show a greater slope with increasing load and changing the dimensions. This is due to the increase in sample consolidation. According to Jenike (1980), the consolidation is a function of the pressures exerted on the grain mass and are able to change the density of the grain. With the density change, we observe the increase of the elastic modulus, as it is observed in Figure 4.

The graphs show the moment when the Stress Wave Timer was paused for reading. The decrease of the strains was due to the product accommodations at the time of the measurement of the accelerometer load. In all the quotas, it is possible to observe that variations of the applied load occur in the last section. These can come from the accommodation of the grains in the empty spaces and due to their semicircular shape. The maximum load applied to coffee occurred at quota 3 in repetition 3 , with a value of $8.32 \mathrm{kN}$.
The data obtained by the ultrasonic pulse technique have a similar behavior to those obtained by the universal testing machine, i.e., a gradual increase in the modulus value.

Equation 1 assumes that, with an increase in density and/or velocity, there will be an increase in the elasticity, creating a linear curve. During the readings with the Stress Wave Timer, this behavior was not observed, with peaks or drops of the elastic modulus at some points. The variations of the elastic modulus as a function of density for each reading of height performed in each quota can be observed in Figure 5. For the construction of this graph, the density values were obtained by means of the ratio between the product weight and the volume occupied by it as a function of the movement of the table, and these values were added incrementally and separated only with respect to the reading of height of the Stress Wave Timer apparatus. For each density value, there is a corresponding value of elastic modulus obtained by Equation 1. A higher linearity is observed in the graph corresponding to the reading performed at the height of $200 \mathrm{~mm}$ (b), i.e., at the midpoint of the reference silo. 
Figure 4. Graph Stress (Mpa) x Strain (mm) supplied by the Universal Testing Machine equivalent to the repetition 3 of each quota. a) quota 1 ; c) quota 2 ; c) quota 3.

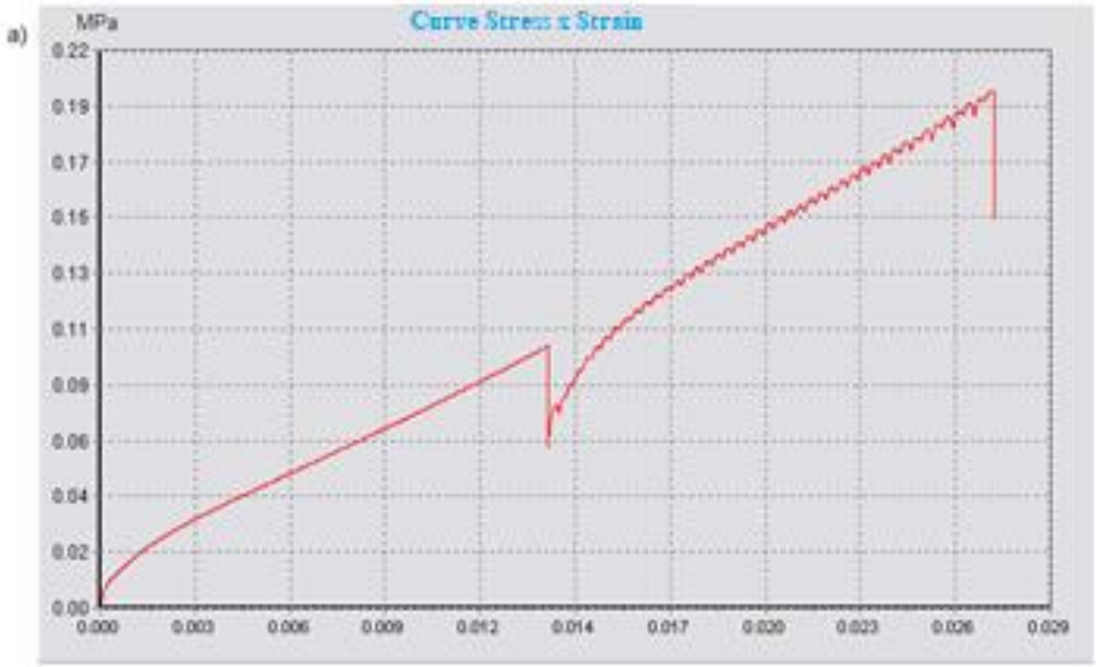

b)
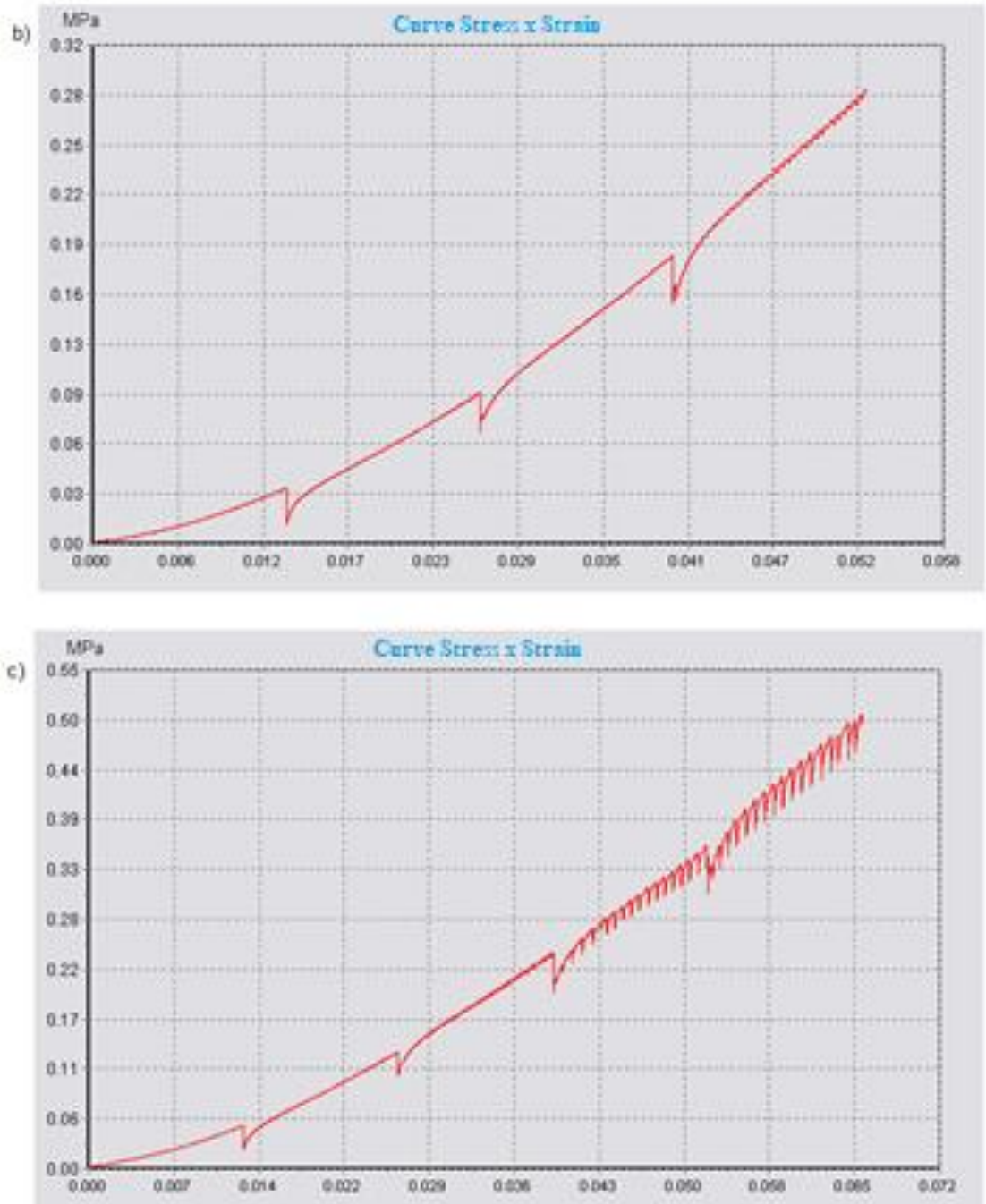
Figure 5. Elastic modulus variation as a function of density. a) Reading at $100 \mathrm{~mm}$. b) Reading at $200 \mathrm{~mm}$. c) Reading at $300 \mathrm{~mm}$.

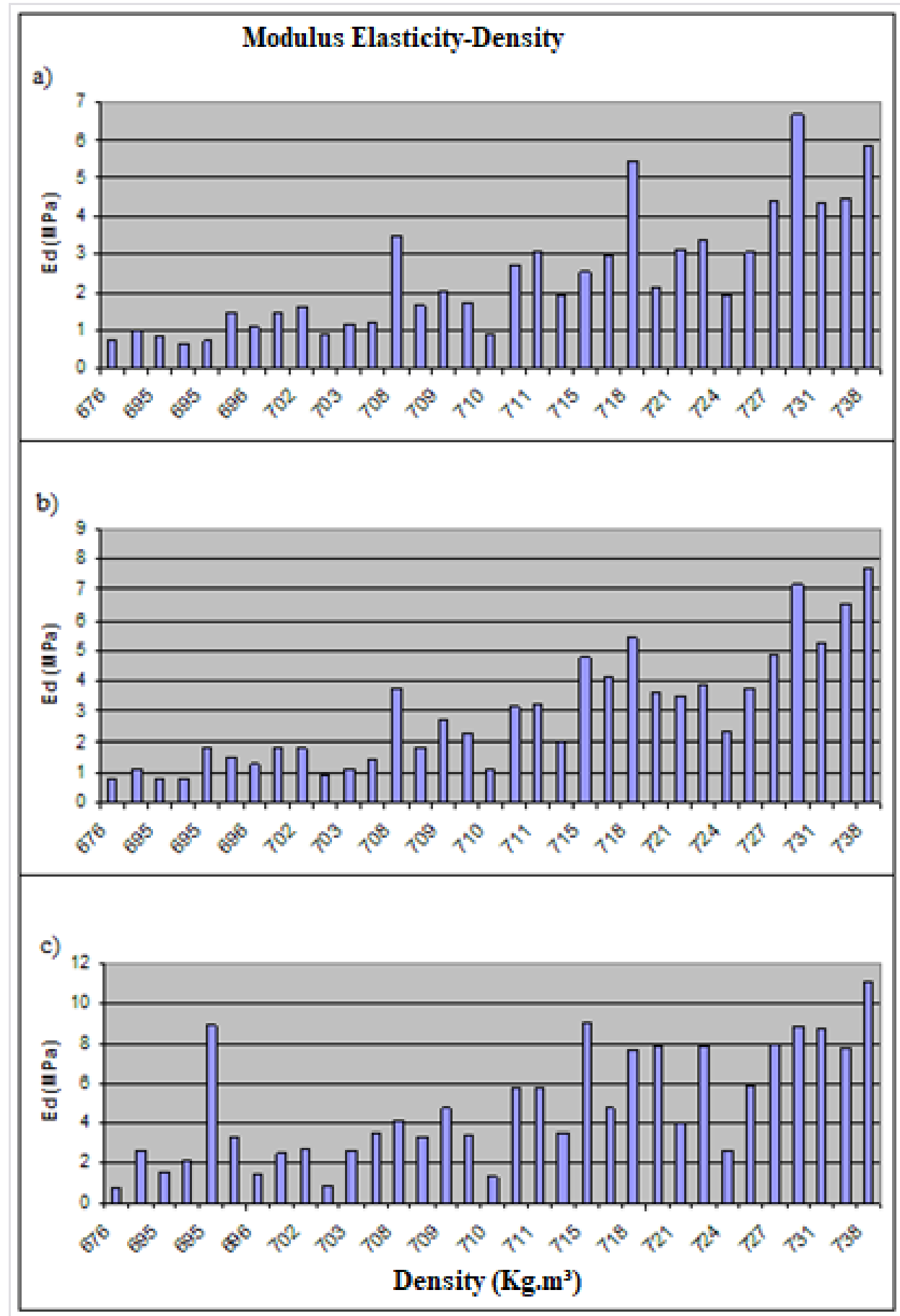

\section{Laboratory tests}

In Table 2, we find the results of the tests applied in the laboratory. It is possible to observe, based on the descriptive classification, the ISD according to the treatments, the results referring to the electrical conductivity and the results of the classification of the coffee beans by the visual evaluation of the X-rays. 
With regard to ISD, the results classify the grains as damaged, even for control (quota 0), and it cannot be possible to determine a great variation among the quotas. The Scott-Knot test indicates quota 3 as the most severe and it is possible to observe a significant increase in the index, signaling a greater amount of external damage, since the control (quota 0 ) obtained the lowest ISD, with a value of $86.37 \%$, and quota 3 obtained the largest, with a value of $94.66 \%$. The tetrazolium test evidenced the external damages, which probably are originated from mechanical processing.

Table 2. ISD, electrical conductivity and internal damage evaluated by x-ray images.

\begin{tabular}{|c|c|c|c|}
\hline Quotas & ISD (\%) & Elect. Conductivity $\left(\mu \mathrm{S} . \mathrm{cm}^{-1} \cdot \mathrm{g}^{-1}\right.$ sample $)$ & Damages (\%) \\
\hline 0 & $86.37 \mathrm{a} 1$ & $188.603333 \mathrm{a} 1$ & $23.66 \mathrm{a} 1$ \\
\hline 1 & 88.55 a1 & $191.226667 \mathrm{a} 1$ & $27.33 \mathrm{a} 1$ \\
\hline 2 & 90.66 a1 & $179.483333 \mathrm{a} 1$ & $35.33 \mathrm{a} 1$ \\
\hline 3 & $94.66 \mathrm{a} 2$ & $182.933333 \mathrm{a} 1$ & $30.00 \mathrm{a} 1$ \\
\hline
\end{tabular}

* Averages followed by the same letter on the columns do not differ among themselves by Scott-Knott test (5\% significance).

It can be verified by the electrical conductivity test that statistically there was no significant difference among the quotas. The lack of differentiation between the control (quota 0 ) and the other quotas probably occurred due to storage being greater than one year and due to the type of processing. Grains have already suffered damage to the membrane even before the quotas.

The data found for the electrical conductivity are in accordance with those obtained by Malta et al. (2005), whose data for coffee beans previously separated in size and without defects, for the sieve grains 16,17 and 18 were $221.77 ; 216.66 ; 210.53$ $\mu \mathrm{S} \mathrm{cm} \mathrm{cm}^{-1} \mathrm{~g}^{-1}$ of sample, respectively. Although the test of this study was not conducted in comparison to the size of the sieves, the grains analyzed here belonged among the sieves 16 and 18. However, these values are far from those obtained by Santos et al. (2009), which presented results of the electrical conductivity as a parameter for their study on the influence of wet processing and drying type, finding for mechanically peeled coffee, with drying in the terrace, the value of $121.56 \mu \mathrm{S} \mathrm{cm}^{-1} \mathrm{~g}^{-1}$ of sample. And from those obtained by Borém et al. (2007), where the worst quality coffee beans obtained for electrical conductivity $85.08 \mu \mathrm{S} \mathrm{cm}^{-1} \mathrm{~g}^{-1}$.
For the damages observed by the x-ray test, it was observed that statistically there was no significant difference among the quotas and among the quotas and the control (quota 0 ). The images obtained with $\mathrm{x}$-rays internally detail the grain, and the parameter used to provide the percentage of damage was the presence of cracks. The impossibility of separating the quotas can be an indication that the loads applied in each quota were not enough to damage the grain internally.

\section{Conclusion}

The compression tests and the Stress Wave Timer apparatus provided elastic modulus values of 6.18 and 4.23 MPa, respectively. Although different from each other, they exhibit the same behavior in function of the increase of the applied load. Such finding can be explained by the consolidation levels obtained in the two test methods.

The tetrazolium test, applied to the endosperm and through the damage severity index, was able to statistically differentiate the applied loads. This difference indicates a deterioration in quality and can be used as a counterpoint to the Stress Wave Timer method. 
The another laboratory tests were not able to statistically differentiate the internal damages for the different loads applied in mechanically processed grains and stored, demonstrating that there is no damage from the loads for a maximum load of 8,32 $\mathrm{kN}$.

The Stress Wave Timer method was able to determine the elastic modulus values for the coffee bean mass and could be used as an indicative of the quality.

\section{Acknowledgements}

To the National Council for Scientific and Technological Development (CNPq) for granting financial support to the research.

\section{References}

ABREU, L. B. D.; LIMA, J. T.; RABELO, G. F.; GOMES, F. C.; TRUGILHO, P. F.; ELOY, F. D. S. Avaliação não destrutiva de estruturas de madeiras em edifício histórico de Tiradentes, MG. Cerne, Lavras, v. 19, n. 3, p. 481-487, 2013.

ANDRADE, R. N. B.; SANTOS, D. S. B.; SANTOS FILHO, B. G.; MELLO, V. D. C. Correlação entre testes de vigor em sementes de cenoura armazenadas por diferentes períodos. Pesquisa Agropecuária Gaúcha, Porto Alegre, v. 1, n. 2, p. 153-162, 1995.

BORÉM, F. M.; RIBEIRO, D. M.; PEREIRA, R. G. F. A.; ROSA, S. D. V. F.; MORAIS, A. R. Qualidade do café submetido a diferentes temperaturas, fluxos de ar e períodos de pré-secagem. Coffee Science, Lavras, v. 1, n. 1, p. 55-63, 2007.

BRASIL. Ministério da Agricultura, Pecuária e Abastecimento Secretaria de Defesa Agropecuária. Regras para análise de sementes. Ministério da Agricultura, Pecuária e Abastecimento Secretaria de Defesa Agropecuária. Brasília: MAPA/ACS, 2009. 399 p.

CHRIST, M.; KIM, Y.; PARK, J. The influence of temperature and cycles on acoustic and mechanical properties of frozen soils. KSCE Journal of Civil Engineering, Seoul, v. 13, n 3, p 153-159, 2009.
CHUNG, Y. C.; OOI, J. Y. Confined compression and rod penetration of a dense granular medium: discrete element modelling and validation. Modern Trends in Geomechanics, Vienna, v. 106, p. 223-239, 2006.

EN 1991-4 Eurocode 1: basis of design and actions on structures. Part 4: Actions in silos and tanks. 2006.

FREITAS, M. N.; Métodos fisiológicos, bioquímicos $e$ análise de imagem para avaliar a qualidade do café. 2013. Dissertação (Mestrado em Fitotecnia) Universidade Federal de Lavras, Lavras.

INTERNATIONAL SEED TESTING ASSOCIATION ISTA. International rules for seed testing. Seed Science and Technology, Zurich, 1999. 333 p.

JENIKE, A. W. Storage and flow of solids. Utah, 1980. 197 p. (Bulletin of the University of Utah, n. 123).

JOHNSTONE, M. W. Calibration of DEM models for granular material using bulk physical tests. 2010. Tese (Doctor of Philosophy) - The University of Edinburgh, Edinburgh.

LOEFFLER, T. M.; TEKRONY, D. M.; EGLI, D. B. The bulk conductivity test as na indicator of soybean quality. Journal of Seed Technology, Lansing, v. 12, n. 1, p. 3753, 1988.

MALTA, M. R.; PEREIRA, R. G. F. A.; CHAGAS, S. D. R. Condutividade elétrica e lixiviação de potássio do exsudato de grãos de café: alguns fatores que podem influenciar essas avaliações. Ciência e Agrotecnologia, Lavras, v. 29, n. 5, p. 1015-1020, 2005.

MCKINNEY, R. H. Influence of soil temperature and moisture on infection of wheat seedlings by Helminthosporium sativum. Journal of Agricultural Research, Washington, v. 6, p. 195-218, 1923.

MOHSENIN, N. N. Physical properties of plant and animal materials. New York: Gordon and Breach Science, 1970.

SAATH, R.; BORÉM, F. M.; ALVES, E.; TAVEIRA, J. H. D. S.; MEDICE, R.; CORADI, P. C. Microscopia eletrônica de varredura do endosperma de café (Coffea arabica L.) durante o processo de secagem. Ciência e Agrotecnologia, Lavras, v. 34, n. 1, p. 196-203, 2010.

SANTOS, S. A.; SILVA, R. F.; PEREIRA, M. G.; MACHADO, J. C.; MACHADO, C. F.; BORÉM, F. M.; GOMES, V. M.; TONETTI, O. A. O. X-ray technique application in evaluating the quality of papaya seeds. Seed Science and Technology,Zurich, v. 37, n. 3, p. 776780, 2009. 
SILVA JUNIOR, S. F.; MARQUES, P. V. Ensaios não destrutivos. [s.1.:s.n], 2006. (Apostila).

VIEIRA, M. G. G. C. Testes rápidos para a determinação da viabilidade e da incidência de danos mecânicos em sementes de cafeeiro. UFLA. Boletim Agropecuario, Lavras, v. 26, 34 p., 1998.
WANG, D.; ZHU, Y.; MA, W.; NIU, Y. Application of ultrasonic technology for physical-mechanical properties of frozen soils. Cold Regions Science and Technology, v. 44, n. 1, p. 12-19, 2006.

ZOERB, G. C.; HALL, C. W. Some mechanical and rheological properties of grains. Journal of Agricultural Engineering Research, Silsoe, v. 5, n. 1, p. 83-92. 1960. 